\title{
A novel subspecies of 'Candidatus Liberibacter africanus' found on native Teclea gerrardii (Family: Rutaceae) from South Africa
}

Authors and Affiliation

Ronel Roberts $^{\mathrm{a}, \mathrm{b}}$ and Gerhard Pietersen ${ }^{\mathrm{a}, \mathrm{b}}$

${ }^{a}$ Department of Microbiology and Plant Pathology, Forestry and Agricultural Biotechnology

Institute, University of Pretoria, Pretoria 0002, South Africa

${ }^{\mathrm{b}}$ Plant Microbiology Division, Agricultural Research Council-Plant Protection Research, Private Bag X134, Pretoria 0001, South Africa

Corresponding author:

Gerhard Pietersen: gerhard.pietersen@up.ac.za

Tel: +27124203265

\begin{abstract}
The phloem limited bacterium 'Candidatus Liberibacter africanus' is associated with citrus greening disease in South Africa. This bacterium has been identified solely from commercial citrus in Africa and the Mascarene islands, and its origin may lie within an indigenous rutaceous host from Africa. Recently, in determining whether alternative hosts of Laf exist amongst the indigenous rutaceous hosts of its triozid vector, Trioza erytreae, three novel subspecies of Laf were identified i.e. 'Candidatus Liberibacter africanus subsp. clausenae', 'Candidatus
\end{abstract}


Liberibacter africanus subsp. vepridis' and 'Candidatus Liberibacter africanus subsp. zanthoxyli' in addition to the formerly identified 'Candidatus Liberibacter africanus subsp. capensis'. The current study expands upon the range of indigenous rutaceous tree species tested for liberibacters closely related to Laf and its subspecies. A collection of 121 samples of Teclea and Oricia species were sampled from Oribi Gorge and Umtamvunu nature reserves in KwaZulu Natal.

Total DNA was extracted and the presence of liberibacters from these samples determined using a generic liberibacter TaqMan real-time PCR assay. Liberibacters from positive samples were further characterised through amplification and sequencing of the 16S rRNA, outer-membrane protein ( отp) and 50S ribosomal protein L10 ( $r p l J)$ genes. A single Teclea gerrardii specimen tested positive for a liberibacter and, through phylogenetic analyses of the three genes sequenced, was shown to be unique, albeit closely related to ' $\mathrm{Ca}$. L. africanus' and ' $\mathrm{Ca}$. L. africanus subsp. zanthoxyli'. We propose that this newly identified liberibacter be named 'Candidatus Liberibacter africanus subsp. tecleae'.

\section{Keywords:}

Liberibacter, Teclea gerrardii, Subspecies,

\section{Introduction}

The bacterial genus Liberibacter (class Alphaproteobacteria, family Rhizobiaceae) (Jaqoueix et al. 1994; Garnier et al. 2000) currently comprises six described species including the pathogens associated with huanglongbing or citrus greening in commercial citrus i.e. 'Candidatus 
Liberibacter asiaticus' (Jaqoueix et al. 1994; Garnier et al. 2000), 'Candidatus Liberibacter americanus' (Teixiera et al. 2005) and, 'Candidatus Liberibacter africanus' (Laf) (Jaqoueix et al. 1994; Garnier et al. 2000). Other species described within this genus includes the agent associated with psyllid yellows disease of tomato (Solanum lycopersicum, family Solanaceae) and zebra chip disease of potatoes (Solanum tuberosum) i.e. 'Candidatus Liberibacter solanacearum' (Liefting et al. 2009; Secor et al. 2009), the pear (family Rosaceae) endophyte 'Candidatus Liberibacter europaeus' (Raddadi et al. 2011) and Liberibacter crescens which was identified from mountain papaya (family Caricaceae) (Fagen et al. 2014). All the members within this bacterial taxon are fastidious and to date, only $L$. crescens has successfully been obtained in pure culture (Fagen et al. 2014).

In South Africa, citrus greening disease is considered an economically important disease of citrus, as fruits produced from infected branches are of a reduced quality (McClean and Oberholzer 1965). The agent associated with this disease, Laf, has thus far been associated only with commercial citrus orchards from Africa (Garnier and Bové 1996; Pietersen et al. 2010) and the Mascarene Islands (Garnier et al. 1996) whereas the nearest known relative of Laf based on 16S rRNA sequence data, 'Ca. L. asiaticus', has a near worldwide distribution (Garnier and Bové 1996; Coletta-Filho et al. 2004; Halbert 2005; Saporani et al. 2010). As commercial citrus species are not indigenous to Africa, it is hypothesised that Laf either made a direct host jump from an indigenous rutaceous species to citrus (Da Graca 2008) or evolved from a liberibacter species present on the African continent prior to the introduction of commercial citrus species (Phahladira et al. 2012; Roberts et al. 2015). The evolutionary theory of Laf is supported by the current lack of evidence of Laf occurring in indigenous rutaceous species tested thus far, along with the occurrence of four subspecies to Laf from South Africa identified from indigenous 
rutaceous species. The subspecies recognised are; 'Candidatus Liberibacter africanus subsp. capensis' (LafC) (Garnier et al. 2000), 'Candidatus Liberibacter africanus subsp. clausenae' (LafCl), 'Candidatus Liberibacter africanus subsp. vepridis' (LafV) and 'Candidatus Liberibacter africanus subsp. zanthoxyli' (LafZ) (Roberts et al. 2015). LafCl, LafV and LafZ were identified from the native hosts of the triozid, Trioza erytreae del Guercio (order Hemiptera, family Triozidae) (Moran 1968; Burkhardt and Ovard 2012), the vector of Laf (McClean and Oberholzer, 1965).

During the study in which LafCl, LafV and LafZ were characterised, we proposed that any one of the subspecies could have been placed under selective pressure to adapt to a new host species through the feeding behaviour of $T$. erytreae. We did however caution that additional rutaceous species from Africa must be studied to determine the existence of either an alternative host or, a further possible ancestor of Laf. The aim of the current study therefore was to determine whether South African native Rutaceae belonging to the genera Teclea and Oricia contain Liberibacter sequences either identical or related to other species within this taxon.

\section{Method and Materials}

Leaf samples of Teclea spp and Oricia bachmannii were collected from natural forests in Southern KwaZulu Natal where these genera are known to occur. The GPS coordinates of each sample was recorded and a unique accession number was allocated per sample. Total DNA was extracted from leaf petioles and midribs following the CTAB extraction method previously described (Doyle and Doyle 1990). 
All samples were subjected to a generic Liberibacter TaqMan real-time PCR assay to identify Liberibacter-positive samples as previously described (Roberts et al. 2015). Reactions were performed on a LightCycler 1.5 capillary-based thermocycler (Roche Diagnostics). The fluorescence emitted in the presence of a positive result was detected and measured using LightCycler 1.4 software (Roche Diagnostics). A crossing threshold (Ct) of $\mathrm{Ct}<35$ was selected as a positive/negative threshold.

Liberibacters identified from Teclea and Oricia samples were characterised by amplifying portions of the 16S rRNA, outer-membrane protein (omp) and 50S ribosomal protein L10 (rplJ) genes as described below.

A partial 16S rRNA sequence was amplified using primers OA1/OI2c previously described (Jaqoueix et al. 1996). To obtain the complete 16S rRNA sequence for the various Lafsubspecies, primers Laf16-5F1 (TGTTAGATGCCTTTGGCAAGA) and Laf16-5R1 (ATATTCCCCACTGCTGCCTC) were used to amplify the 16S rRNA at the 5' region and primers Laf16-3F8 (5'-TTAATTCGATGCAACGCGCA-3') and Laf16-3R8 (5'GGACGGCGATCCTCTAAAACC-3') were used to amplify the 3' end of the 16S rRNA sequences. All reactions were set up by adding $0.5 \mu \mathrm{l}$ DNA template to a final reaction volume of $25 \mu 1$ consisting of $12.5 \mu 12 \mathrm{X}$ Dream Taq Green master mix (Thermo Scientific), $10 \mu \mathrm{M}$ per primer per set and made up to a final reaction using molecular-grade water (Sigma-Aldrich). PCR cycling was performed on a T100 Thermal Cycler (Bio-Rad). The following cycling conditions were used; initial denaturation of $92^{\circ} \mathrm{C}$ for $5 \mathrm{~min}$, followed by 35 cycles of denaturation at $92^{\circ} \mathrm{C}$ for $30 \mathrm{~s}$, annealing at $65^{\circ} \mathrm{C}$ for $30 \mathrm{~s}$ and elongation at $72^{\circ} \mathrm{C}$ for $90 \mathrm{~s}$, final elongation was carried out at $72^{\circ} \mathrm{C}$ for $10 \mathrm{~min}$. 
Partial amplification of the omp gene region was achieved through utilising primers omp1/omp8inv as previously described (Bastianel et al. 2005). Reactions were set up as for the $16 \mathrm{~S}$ rRNA amplification using the following cycling conditions; initial denaturation at $92^{\circ} \mathrm{C}$ for 5 min, 35 cycles of denaturation at $92^{\circ} \mathrm{C}$ for $30 \mathrm{~s}$, annealing at $50^{\circ} \mathrm{C}$ for $30 \mathrm{~s}$, elongation at $72^{\circ} \mathrm{C}$ for $2 \mathrm{~min}$, followed by a final extension of $72^{\circ} \mathrm{C}$ for $10 \mathrm{~min}$.

A portion of the Liberibacter $r p l J$ gene was amplified using primers A2/J5 as previously designed (Hocquellet et al. 1999). The reaction was set up as for the 16S rRNA gene amplification and cycling conditions were performed as previously described (Roberts et al. 2015).

Amplification products of each gene region were purified enzymatically using exonuclease I (Fermentas) and FastAP (Werle et al. 1994). Purified amplicons per gene region were sequenced in both directions with corresponding primers using the Big Dye Terminator version 3.1 cycle sequencing kit (ABI) according to the manufacturer's instructions. The amplicon sequences were determined using an ABI 3500xL automated sequencer at the University of Pretoria, South Africa.

The DNA sequences obtained were compiled into different datasets along with relevant reference sequences obtained from Genbank. Reference sequences consisted of known sequences of other citrus infecting members within the genus Liberibacter. Each dataset was aligned using the online alignment tool Mafft (Katoh et al. 2002). Following alignment, each dataset was trimmed in BioEdit version 7.0.9.0 (Hall 1999) to obtain equal length sequences. The best-fit substitution model for each dataset was determined by jModelTest (Posada 2008) and maximum- 
likelihood phylogenetic analyses was performed using MEGA software version 6.06 (Tamura et al. 2013)

To verify the nature of the tree species sampled, the extracted DNAs were subjected to DNA barcoding through amplification of two DNA barcodes for plants ( $r b c L$ gene, large subunit of ribulose-1,5-biphosphate carboxylase, and $p s b A$-trnH intergenic spacer; Chase et al. 2005, Pang et al. 2012). PCR reactions for both regions were set up using the DreamTaq Green system as discussed earlier. Amplification of $r b c L$ was performed with primers rbcLa F/rbcLa R (Levin et al. 2003, Kress and Erickson 2007) using conditions previously described (Roberts et al. 2015). The $p s b A$-trnH intergenic spacer region was amplified by utilising primers psbA3_f/trnHf_05 (Sang et al. 1997, Tate and Simpson 2003) under the following conditions; initial denaturation at $92^{\circ} \mathrm{C}$ for $3 \mathrm{~min}, 35$ cycles of denaturation $92^{\circ} \mathrm{C}$ for $20 \mathrm{~s}$, annealing $58^{\circ} \mathrm{C}$ for $20 \mathrm{~s}$, extension $72^{\circ} \mathrm{C}$ and final extension at $72^{\circ} \mathrm{C}$ for 5 min. Amplification products were purified and sequenced as before and phylogenetic analyses was performed as previously described.

\section{Results}

A total of 95 Teclea and 27 O. bachmannii specimens were sampled. A few samples displayed triozid depression marks similar to those made by $T$. erytreae, although no triozid specimens were obtained on these samples. Sampling was conducted in the Oribi Gorge and Umtamvunu nature reserve as the distribution of the tree species studied is limited along the eastern seaboard of South Africa (Waffo et al. 2006). A single Teclea spp. specimen (Accession number 13-2189) gave a positive result in the generic Liberibacter test and was further analysed. 
PCR amplification of the $16 \mathrm{~S}, r p l J$ and $о m p$ gene regions for the liberibacter positive Teclea sample yielded amplification products corresponding in size to liberibacter-positive controls. All healthy and 'no template' controls remained negative. The complete liberibacter 16S rRNA sequence obtained (1501 nt; Genbank Accession KX990288) shares a nucleotide identity of 99.3\% with that of Laf, $99.6 \%$ with $\mathrm{LafZ}$ and $98.8 \%$ with $\mathrm{LafC}, \mathrm{LafCl}$ and $\mathrm{LafV}$. When compared to sequences from ' $C a$. L. asiaticus'and ' $C a$. L. americanus', the newly obtained Teclea liberibacter sequence shares a nucleotide identity of $98.0 \%$ and $95.0 \%$, respectively. Phylogenetic analyses of the 16S rRNA confirmed that the sequence obtained from Teclea is more closely related to Laf and all its known subspecies than other Citrus spp. infecting liberibacter species (Fig. 1). While the 16S rRNA gene of African liberibacters are highly conserved, as previously demonstrated (Roberts et al. 2015), the 16S rRNA sequence obtained from Teclea is found in a separate clade, albeit closely related to LafZ.

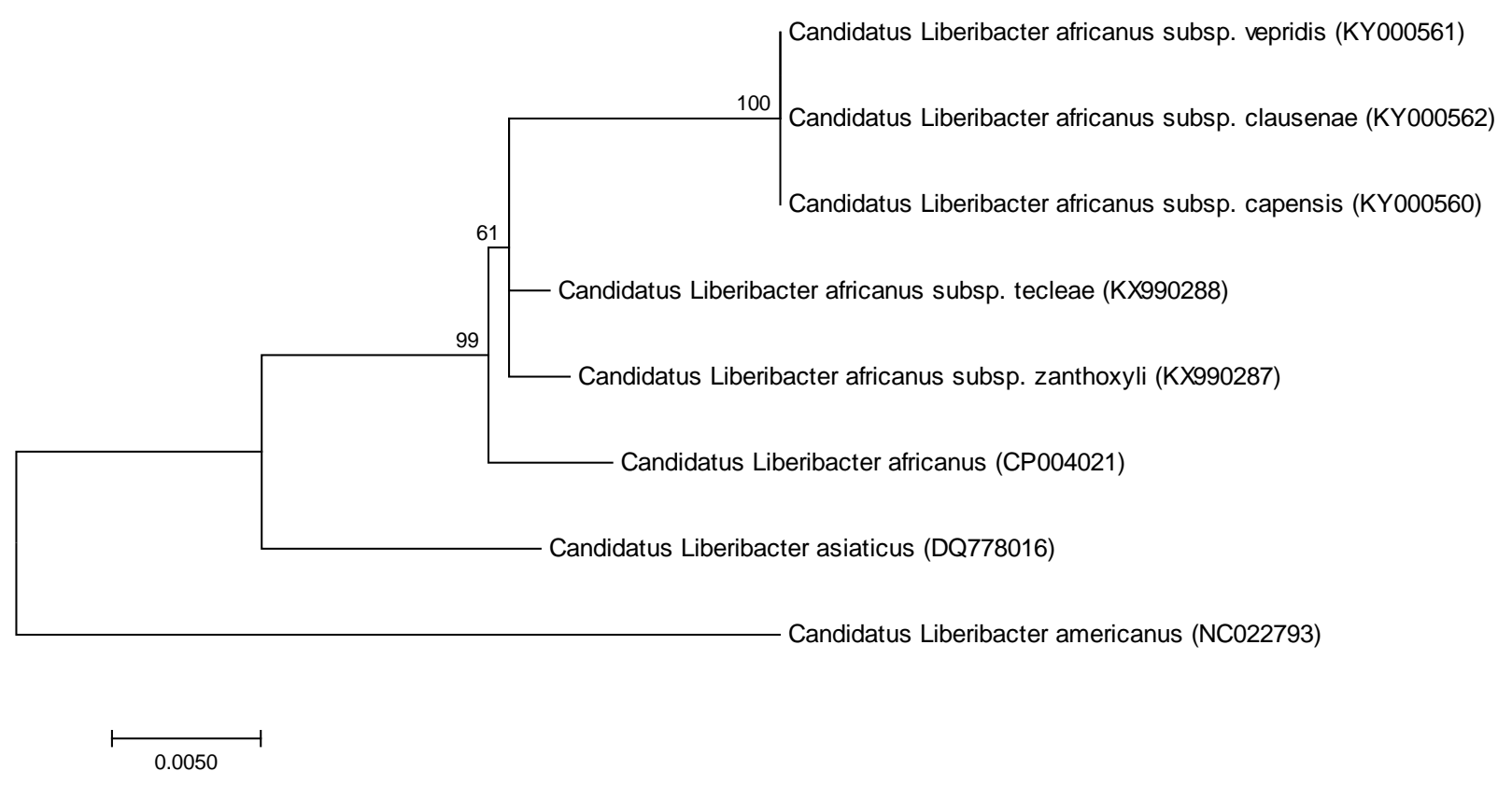


Fig. 1. Maximum-likelihood phylogeny based on $16 \mathrm{~S}$ rRNA gene sequences of citrus associated members within the genus Liberibacter including the sequence obtained from the Teclea gerrardii sample examined in this study. Phylogeny was inferred using Hasegawa-Kishino-Yano mode (Hasegawa et al., 1985) with gamma correction to account for site variation. Bootstrap support values based on 1000 replicates are indicated at branches. GenBank (http://www.ncbi.nlm.nih.gov/Genbank/index.html) accession numbers are shown on the tree for sequences included in this analysis. Bar, 0.005 substitutions per nucleotide position.

For, respectively, omp (Genbank accession KU561668) and rplJ (Genbank accession KU561667) sequences, nucleotide similarities between the corresponding Teclea liberibacter sequences and those of Laf (87.4\% and 86.9\%) and LafZ (89.2\% and 84.8\%) were greater than those for $\mathrm{LafC}$ (78.9\% and $78.2 \%), \mathrm{LafCl}(79.0 \%$ and $79.2 \%)$ and $\mathrm{LafV}(79.5 \%$ and $76.3 \%)$. Compared to 'Ca. L. asiaticus' omp and $r p l J$ sequences, the liberibacter ex Teclea shared 73.3\% and $72.0 \%$ overall sequence identity, respectively. Phylogenetic analysis of these two genes placed the liberibacter sequence obtained from Teclea into a separate clade, closely related to Laf and LafZ (Fig. 2; Fig 3).

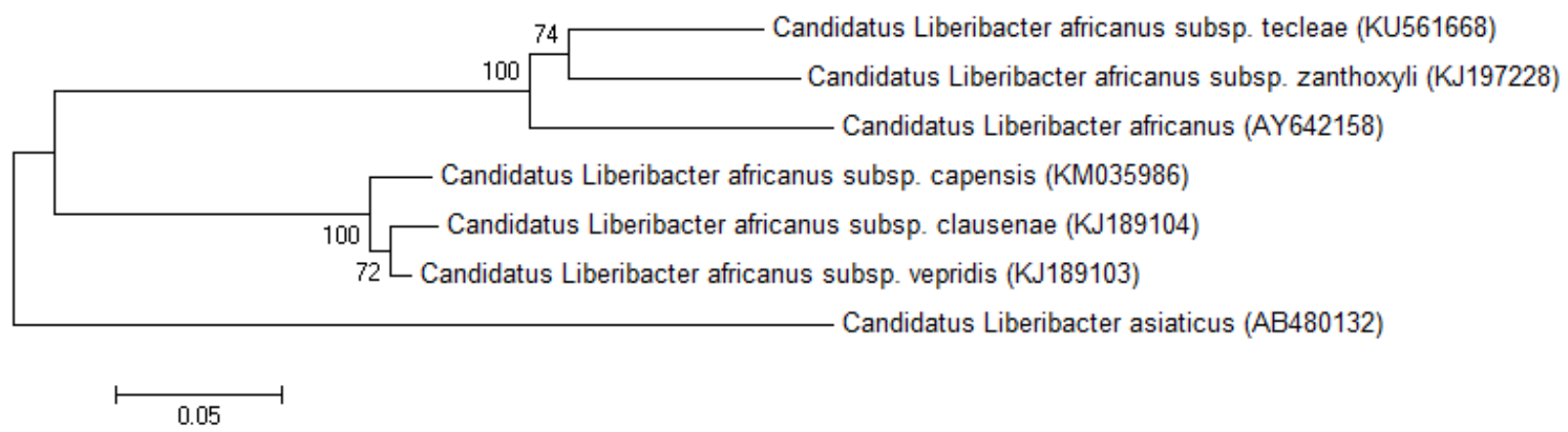

Fig. 2. Maximum-likelihood phylogeny based on available omp gene sequences of members within the genus Liberibacter which are associated with rutaceous species. The phylogeny was inferred using the general time reversible model with gamma correction to account for site variations. Bootstrap support values based on 1000 replicates are indicated at branches. GenBank (http://www.ncbi.nlm.nih.gov/Genbank/index.html) accession 
numbers are shown on the tree for sequences included in this analysis. Bar, 0.05 substitutions per nucleotide position.

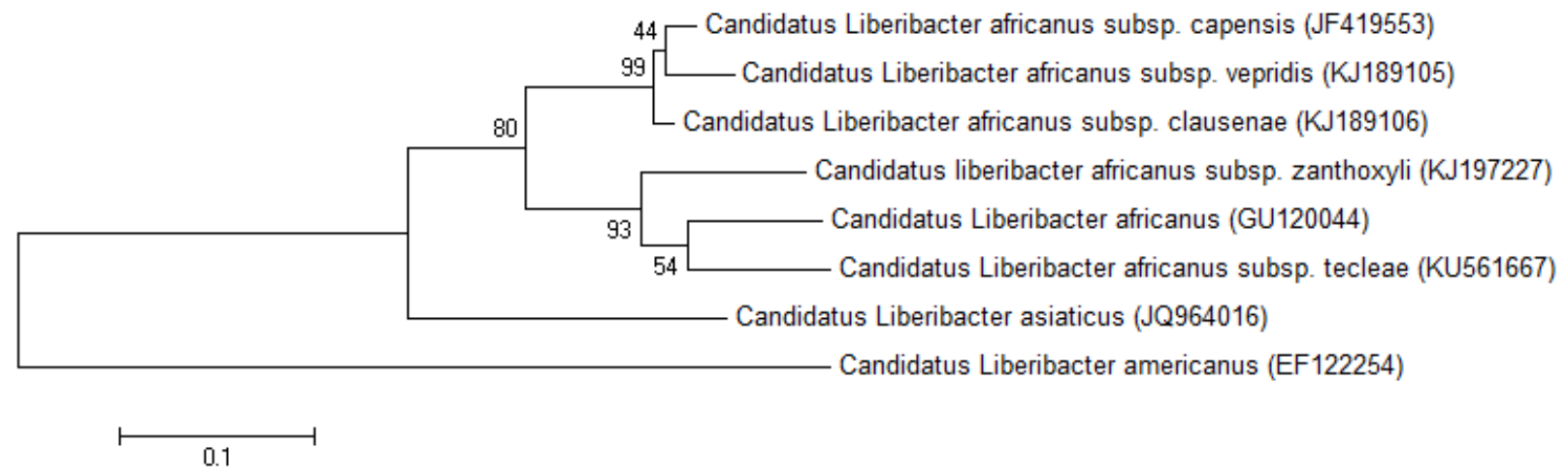

Fig. 3. Maximum-likelihood phylogeny based on $r p l J$ gene sequences of members within the genus Liberibacter which are associated with rutaceous species. The phylogeny was inferred using the Tamura-Nei model (Tamura and Nei, 1993) with gamma correction to account for site variations. Bootstrap support values based on 1000 replicates are indicated at branches. GenBank (http://www.ncbi.nlm.nih.gov/Genbank/index.html) accession numbers are shown on the tree for sequences included in this analysis. Bar, 0.01 substitutions per nucleotide position.

To confirm the identity of the Teclea host from which the novel liberibacter sequences were obtained, all samples collected were subjected to DNA barcoding by sequencing $r b c L$ and $p s b$ $\operatorname{trn} H$ gene regions. The $r b c L$ gene for all samples collected was successfully amplified, however this gene sequence could not resolve between $O$. bachmannii and the two Teclea species known to occur is South Africa (i.e. Teclea natalensis and Teclea gerrardii I. Verd) (Waffo et al. 2006) (Fig. 4). Of the 122 samples subjected to DNA barcoding of the $p s b$-trnH gene, only 94 samples were successfully sequenced, with 14 putative $O$. bachmannii and 14 putative Teclea spp. failing to amplify. Phylogenetic analyses of this plastid gene region resolved various closely related rutaceous species within the genera Oricia, Teclea and Vepris into separated clades (Fig. 5). Based on these results, it was shown that the tree host of the liberibacter positive sample studied here is T. gerrardii. A cluster of 26 samples formed a clade distinct from, but closely related to, 
other Oricia and Teclea clades suggesting the presence of hereto undescribed variability in the taxonomy of this genus requiring further studies. A voucher specimen of tree sample 13-2192 was deposited with the KwaZulu-Natal Herbarium under the Voucher number "A.M. Ngwenya 4433". A sample of the original infected plant material has been deposited in the National Collection of Plant Virus and Antisera at the ARC-Plant Protection Research Institute (http://www.arc.agric.za/arc-ppri/Pages/ARC-PPRI-Homepage.aspx), under accession number 13-2189.

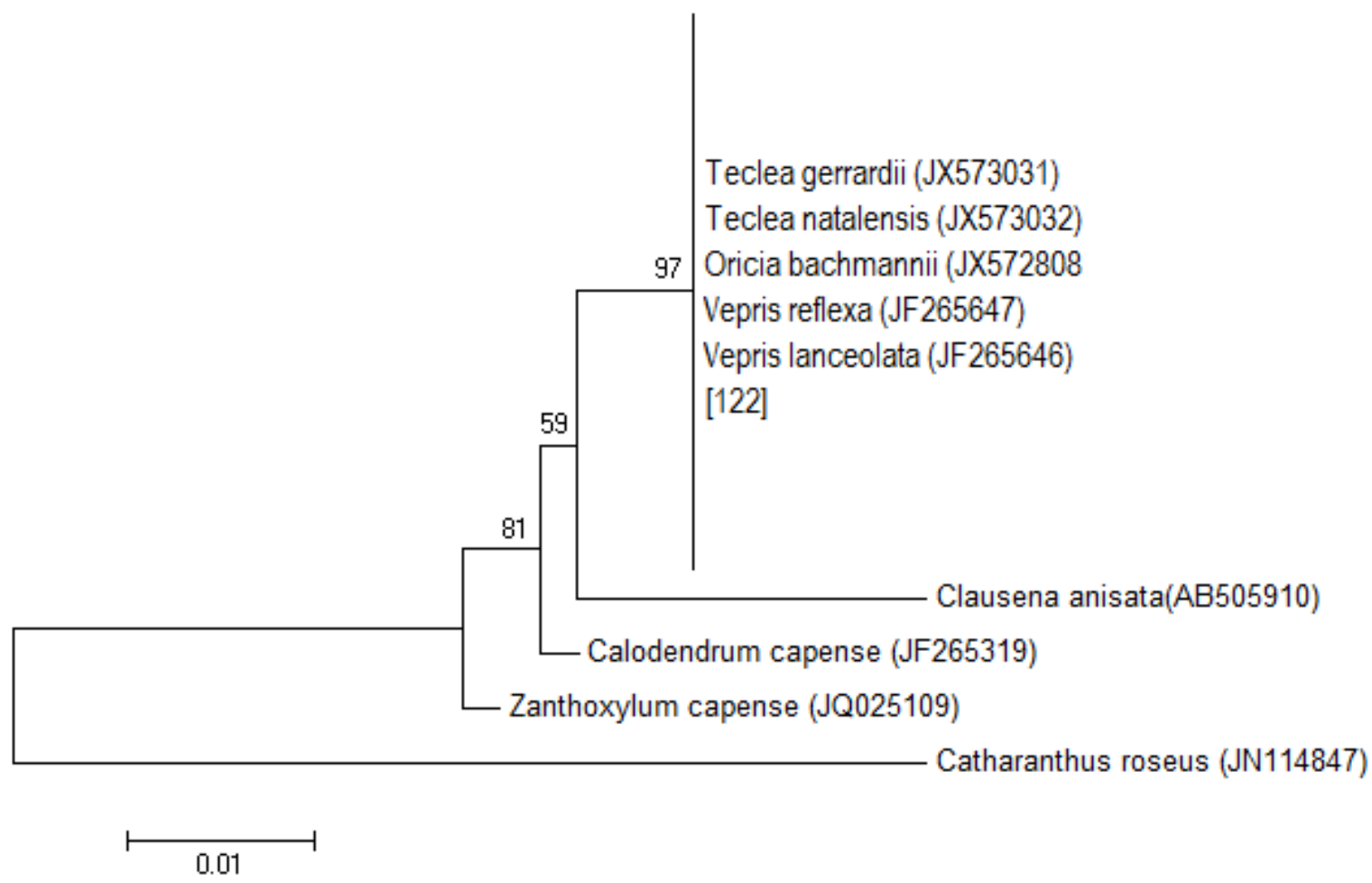

Fig. 4. Maximum-likelihood phylogeny of tree host species based on $r b c L$ sequences obtained from all Oricia and Teclea samples collected for this study. The phylogeny was inferred using the Jukes-Cantor model. Bootstrap values based on 1000 replicates are indicated at branch nodes. Branches with $>70 \%$ bootstrap support for terminal taxa were collapsed. The 122 specimens which were successfully sequenced are indicated in brackets. Bar, 0.01 substitutions per nucleotide position. 


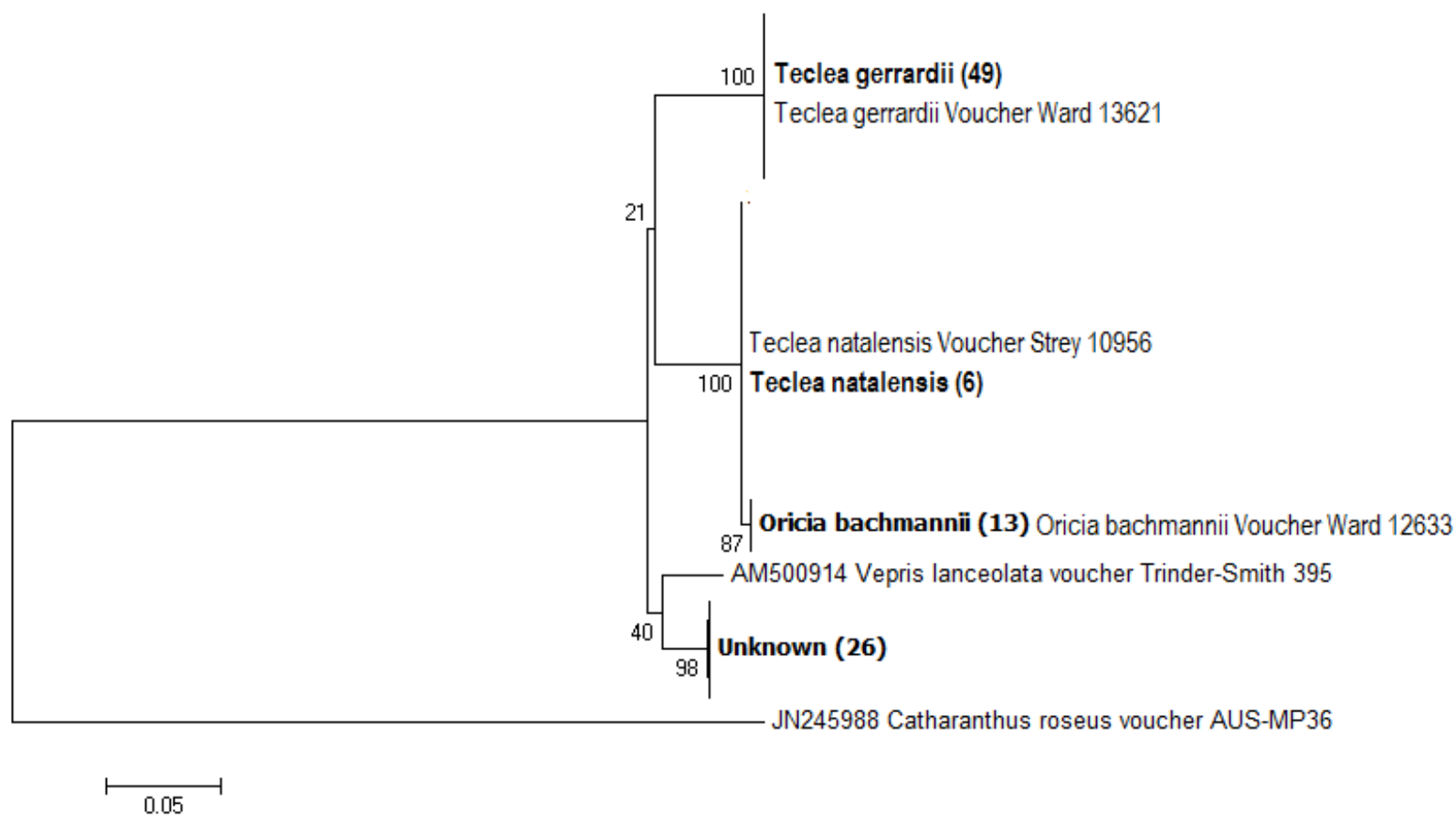

Fig. 5. Maximum-likelihood phylogeny of tree host species based on psb-trnH sequences obtained from Oricia and Teclea samples collected in this study (indicated in bold) as well as voucher specimens representing the tree species studied obtained from the South African National Biodiversity Institute (SANBI).). The phylogeny was inferred using Tamura's 3-parameter model (Tamura, 1992). Bootstrap support values based on 1000 replicates are indicated at branch nodes. Branches with $>70 \%$ bootstrap support for terminal taxa were collapsed. The number of specimens sequenced per tree species in indicated in brackets. Bar, 0.05 substitutions per nucleotide position.

\section{Discussion}

The percentage nucleotide identity of the 16S rRNA sequence obtained for the single liberibacter positive T. gerrardii sample conforms to the $>99 \%$ nucleotide identities found amongst previously characterised Laf subspecies (Garnier et al. 2000; Roberts et al. 2015). From the overall sequence similarity described here, and the phylogenies for all three gene regions studied, it is apparent that the sequences obtained from the single liberibacter positive $T$. gerrardii 
represents a novel liberibacter sequence closely related to Laf and its subspecies. In maintaining previous convention, we therefore propose that the liberibacter obtained from Teclea also be assigned subspecies status under the proposed name of 'Candidatus Liberibacter africanus subsp. tecleae' (te.cle'ae. N.L. gen. n. tecleae, meaning of the plant genus Teclea), abbreviated to Laf).

It has recently been suggested that the various subspecies of Laf represents haplotypes of Laf based on 16S rRNA data (Nelson et al. 2015). However, the five Laf subspecies described (LafC, LafCl, LafV, LafZ and now LafT) were generally identified from multiple specimens, LafT being the exception, of specific host species only, suggesting that gene-flow between these various liberibacters is limited, supporting the higher taxonomic status afforded by subspecies classification. The high conservation of the 16S rRNA gene of African liberibacters does however suggest that the divergence and isolation of these subspecies within their respective hosts occurred more recently than the divergence of Laf from ' $\mathrm{Ca}$. L. asiaticus', which is estimated at $150 \mathrm{Myr}$ (Teixiera et al. 2008). The subspecies designation thus aims to describe the relatedness of the various subspecies to Laf along with the distinction based on the various rutaceous hosts they occupy.

With the addition of LafT, there are now five recognised subspecies to Laf which have been identified from South Africa. For the benefit of the South African citrus industry, it will be important to fully characterise various biological properties of these liberibacter subspecies i.e. vector and host range, to help fully understand the possible impact these liberibacters may have on commercial citrus crops. Additional sequence information LafC, LafCl, LafV, LafT and LafZ could potentially help clarify the exact taxonomic position of the various subspecies in relation to Laf and give further insight into the divergence of these liberibacters. 


\section{Acknowledgments}

We would like to thank Citrus Research International (CRI), the National Research FoundationTHRIP program (NRF-THRIP) and the Department of Science and Technology (DST)/NRF Centre of Excellence in Tree Health Biotechnology (CTHB) for funding. We would also like to thank Dr. Hugh Glen for his assistance in naming the novel liberibacter subspecies described herein and Prof. Aharon Oren, Hebrew University of Jerusalem, for help with the etymology and syllabification of the name.

\section{References}

Bastianel C, Garnier-Semancik M, Renaudin J, Bové JM, Eveillard S (2005) Diversity of 'Candidatus Liberibacter asiaticus' based on the omp gene sequence. Appl Environ Microb 71:6473-6478.

Burckhard D, Ouvrard D (2012) A revised classification of the jumping plant-lice (Hemiptera: Psylloidea). Zootaxa 3509:1-34.

Chase MW, Salamin N, Wilkinsin M, Dunwell JM, Kesanakurthi RP, Haidar N, Savolainen V (2005) Land plants and DNA barcodes: short term and long term goals. Philos Trans R Soc Lond B Biol Sci 360:1889-1895. 
Coletta-Filho HD, Targon MLPN, Takita MA, De Negri JD, Pompeu J, Jr, Machado MA, do Amaral AM, Muller GW (2004) First report of the causal agent of huanglongbing ('Candidatus Liberibacter asiaticus') in Brazil. Plant Dis 88:1382.

da Graça JV (2008) Biology, history and world status of Huanglongbing. In I Taller Internacional sobre Huanglongbing de los citricos (Candidatus Liberibacter spp) y el psílido asiático de los cítricos (Diaphorina citri) Hermosillo, Sonora, Mexico. pp 1-7.

Doyle JJ, Doyle JL (1990) Isolation of plant DNA from fresh tissue. Focus 12:13-15

Fagen JR, Leonard MT, Coyle JF, McCullough CM, Davis-Richerdson AG, Davie MJ, Triplett EW (2014) Liberibacter crescens gen. nov., sp. nov., the first cultured member of the genus Liberibacter. Int J Syst Evol Micr 64:2461-2466.

Garnier M, Bové JM (1996) Distribution of the huanglongbing (greening) Liberobacter species in fifteen African and Asian countries. In Proceedings of the Thirteenth Conference of the International Organization of Citrus Virologists, pp. 388-391. Edited by J. V. da Graça, R. F. Lee and R. K. Yokomi. Riverside, CA: University of California Riverside.

Garnier M, Jaqoueix-Eveillard S, Cronje PR, Le Roux HF, Bové JM (2000) Genomic characterization of a liberibacter present in an ornamental rutaceous tree, Calodendrum capense, in the Western Cape Province of South Africa. Proposal of 'Candidatus Liberibacter africanus subsp. capensis' Int J Syst Evol Micr 50:2119-2125.

Garnier M, Jaqoueix S, Toorawwaw P, Grisoni M, Mallessard R, Dookun A, Saumtally S, Autrey JC, Bové JM (1996) Both huanglongbing (greening) Liberibacter species are present in Mauritius and Réunion. In Proceedings of the Thirteenth Conference of the International 
Organization of Citrus Virologists, pp. 388-391. Edited by J. V. de Graça, R. F. Lee and R. K. Yokomi. Riverside, CA: University of California Riverside.

Halbert SE (2005) The discovery of Huanglongbing in Florida. In Proceedings of the Second International Citrus Canker and Huanglongbing Research Workshop, abstract H-3. Orlando: Florida Citrus Mutual.

Hall TA (1999) BioEdit: a user-friendly biological sequence alignment editor and analysis program for windows 95/98/NT. Nuc Acids S 41:95-98

Hasegawa M, Kishino H, Yano T (1985). Dating the human-ape split by a molecular clock of mitochondria DNA. Journal of Molecular Evolution 22:260-174

Hocquellet A, Toorawa P, Bové JM, Garnier M (1999) Detection and identification of the two Candidatus Liberobacter species associated with citrus huanglongbing by PCR amplification of ribosomal protein genes of the $\beta$ operon. Mol Cell Probe 13:373-379.

Jagoueix S, Bové JM, Garnier M (1994) The phloem-limited bacterium of greening disease is a member of the $\alpha$ subdivision if the Proteobacteria. Int J Syst Bacteriol 44:379-386.

Jagoueix S, Bové JM, Garnier M (1996) PCR detection of the two 'Candidatus' Liberobacter species associated with greening disease of citrus. Mol Cell Probe 10:43-50.

Katoh K, Misawa K, Kuma K, Miyata T (2002) MAFFT: A novel method for rapid multiple sequence alignment based on fast Fourier transform. Nucl Acid Res 30:3059-3066.

Kimura M (1980) A simple method for estimating evolutionary rates of base substitutions through comparative studies of nucleotide sequences. J Mol Evol 16:111-120. 
Kress WJ, Erickson DL (2007) A two-locus global DNA barcode for land planrs: the coding $r b c L$ gene complements the non-coding trnH-psbA spacer region. PLoS ONE 2:e508.

Levin RA, Wagner WL, Hoch PC, Nepokroeff M, Pires JC, Zimmer EA, Sytsma KJ (2003) Family-level relationships of Onagraceae based on chloroplast $r b c L$ and $n d h F$ data. Am J Bot 90:107-115.

Liefting LW, Weir BS, Pennycook SR, Clover GRG (2009) 'Candidatus Liberibacter solanacearum', associated with plants in the family Solanaceae. Int J Syst Evol Micr 59:22742276.

McClean APD, Oberholzer PCJ (1965) Citrus psylla, a vector of the greening disease in sweet orange. S Afr J Agric Sci 8:297-298.

Moran VC (1968) The development of the citrus psylla, Trioza erytreae (del Guercio) (Homoptera: Psyllidae), in Citrus limon and four indigenous host plants. J Entomol Soc S Afr 31:391-402.

Nelson WR, Eveillard S, Dubrana MP, Bové JM (2015) Cryptic haplotypes of 'Candidatus Liberibacter africanus'. J Plant Pathol 97:291-295.

Pang X, Liu C, Shi L, Lium RM, Liang, D, Li H, Cherny SS, Chen S (2012) Utility of the trnH$p s b A$ intergenic spacer region and its combinations as plant DNA barcodes: A meta-analysis. PLoS ONE 7(11):e48833. Doi:10.1371/journal.pone.0048833. 
Phahladira MNB, Viljoen R, Pietersen G (2012) Widespread occurrence of "Candidatus Liberibacter africanus subspecies capensis' in Calodendrum capense in South Africa. Eur J Plant Pathol 134:39-47.

Pietersen G, Arrebola E, Breytenbach JHJ, Korsten L, Le Roux HF, la Grange H, Lopes SA, Meyer JB, Pretorius MC, Schwerdtfeger M, van Vuuren SP, Yamamoto P (2010) A survey for 'Candidatus Liberibacter' species in South Africa confirms the presence of only ' $\mathrm{Ca}$. L, africanus' in commercial citrus. Plant Dis 94:244-249.

Posada D (2008) jModelTest: Phylogenetic model averaging. Mol Biol Evol 25:1253-1256.

Raddadi N, Gonella E, Camerota C, Pizzinat A, Tedeschi R, Crotti E, Mandrioli M, Attilio Bianco P, Daffonchio D, Alma A (2011) 'Candidatus Liberibacter europeas' sp. nov. that is associated with and transmitted by the psyllid Cacopsylla pyri apparently behaves like an endophyte rather than a pathogen. Environmental Microbiology 13:414-426.

Roberts R, Steenkamp ET, Pietersen G (2015) Three novel lineages of 'Candidatus Liberibacter africanus' associated with native rutaceous hosts of Trioza erytreae in South Africa. Int J Sys Evol Micr 65:723-731.

Sang T, Grawford DJ, Stuessy TF (1997) Chloroplast DNA phylogeny, reticulate evolution, and biogeography of Paeonia (Paeoniaceae). American Journal of Botany 84: 1120-1136.

Saponari M, De Bac G, Breithaupt J, Loconsole G, Yokomi RK, Catalano L (2010) First report of 'Candidatus Liberibacter asiaticus' associated with huanglongbing in sweet orange in Ethiopia. Plant Dis 93:482. 
Secor GA, Rivera VV, Abad JA, Lee I.-M, Clover GRG, Liefting LW, Li X, De Boer SH (2009) Association of 'Candidatus Liberibacter solanacearum' with zebra chip disease of potato established by graft and psyllid transmission, electron microscopy and PCR. Plant Dis 93:574583.

Tamura K, Stecher G, Peterson D, Filipski A, Kumar S (2013) Mega 6: Molecular evolutionary Genetics Analysis version 6.0. Mol Biol Evol 30:2725-2729.

Tamura K, Nei M (1993) Estimation of the number of nucleotide substitutions in the control region of mitochondrial DNA in humans and chimpanzees. Mol Biol Evol 28:2731-2739.

Tamura K (1992) Estimation of the number of nucleotide substitutions when there are strong transition-transversion and G+C content biases. Mol Biol Evol 9:678-687.

Tate JA, Simpson BB (2003) Paraphyly of Tarasa (Malvaceae) and diverse origins of the polyploid species. Syst Bot 28:723-737.

Teixeira DC, Ayres J, Kitajima EW, Danet L, Jaqoueix-Eveillard S, Saillard C, Bové JM (2005) First report of a Huanglongbing-like disease of citrus in São Paulo state, Brazil and association of a new Liberibacter species, 'Candidatus Liberibacter americanus', with the disease. Plant Dis 89:107.

Teixeira DC, Eveillard S, Sirand-Pugnet P, Wulff A, Saillard C, Ayres AJ, Bové JM (2008) The tufB-secE-nusG-rplKAJL-rpoB gene cluster of the liberibacters: sequence comparisons, phylogeny and speciation. Int J Sys Evol Micr 58:1414-1421. 
Waffo AFK, Coombes PH, Crouch NR, Mulholland DA, El Amin SMM, Smith PJ (2006) Acridone and furoquinoline alkaloids from Teclea gerrardii (Rutaceae: Toddioideae) of southern Africa. Phytochemistry 68:663-667.

Werle E, Schneider C, Renner M, Völker M, Fiehn W (1994) Convenient single-step, one tube purification of PCR products for direct sequencing. Nucl Acids Res 22:4354-4355. 